\title{
An Analysis on the Reading Habits of University Students Studying Physical Education and Sports Training
}

\author{
Cansel Arslanoğlu ${ }^{1, *} \&$ Ahmet Mor ${ }^{1}$ \\ ${ }^{1}$ Faculty of Sports Sciences, Sinop University, Sinop, Turkey \\ *Correspondence: Faculty of Sports Sciences, Sinop University, Sinop, Turkey. Tel: 368-271-4155. E-mail: \\ canseloglu@sinop.edu.tr
}

Received: June 22, 2018

Accepted: July 18, $2018 \quad$ Online Published: August 8, 2018

doi:10.5430/wje.v8n4p102

URL: https://doi.org/10.5430/wje.v8n4p102

\begin{abstract}
The aim of this research is to analyze the reading habits of students studying physical education and sports training with respect to certain variables. A total of 324 first-year students (125 females, 199 males) voluntarily participated in the research from physical education and sports training departments of Sinop University, Kafkas University, and Ondokuz Maÿ̈s University. A questionnaire consisting of two parts was used as the data collection tool in the research. The personal information form was used in the first part and the "Reading Habit Attitude Scale" developed by Gömleksiz (2004) was used in the second part. Shapiro Wilk and Levene tests were employed to determine whether the data exhibited a normal distribution in the analysis. The data exhibiting a normal distribution were analyzed with the help of t-test and One-Way ANOVA. In multiple comparisons, the Tukey HSD test was used to determine the groups causing the difference. According to the results of the research, a significant difference was found in favor of women in the age variable of sub-dimensions of "love, habit, will, effect and benefit"; in the gender variable; in favor of ages 18-20-21-22 in sub-dimension of "necessity"; in favor of primary and secondary school graduates in sub-dimensions of "habit, necessity and will" in the father's educational background variable; in favor of the average value above 1.5 in sub-dimension of "love" and in favor of average grades between 1.0-2.5 in sub-dimension of "benefit" in the academic grade averages variable $(\mathrm{p}<0.05)$. No significant difference was found with respect to the variables of the department and mother's education background ( $p>0.05)$.

It was revealed that among the university students studying physical education and sports training, female students read more than the male students and those whose father was a primary or secondary school graduate were more willing to read and they regarded this habit as a necessity.
\end{abstract}

Keywords: reading habits, physical education and sports, university student

\section{Introduction}

Rapid developments experienced in various fields today have made it inevitable for individuals to develop new and intellectual perspectives and develop original habits with new value judgments. What is expected from individuals is to acquire these skills and to use them for the benefit of the society. There are certain qualities that must be acquired by every individual who goes through the process of training. One of these qualities is the acquisition of a book reading habit (Durmuş and Baş, 2016). Reading is defined as a complex process consisting of various development stages and creating new thoughts in mind (Geçgel and Burgul 2009; Yılmaz 2010).

A society with modern, creative, constructive, liberal, productive and critical individuals can only be possible with individuals instilled with the consciousness about reading. This is because a society can adapt to the developments and changes by forming the consciousness about reading. The most basic requirement for gaining this consciousness is to love reading. The most persistent and important factor needed in the process of raising consciousness about reading is that reading should be turned into a habit. Reading habit is defined as the individual's perceiving reading as a necessity and continuing the reading activity regularly in every stage of life. This habit is a skill that students must basically acquire during their school years. If students do not acquire this skill while they are at school age, it is rather difficult to acquire it in adulthood (Şahin, 2012). Reading is one of the basic skills that become influential throughout the lives of individuals. Individuals with good reading skills are known to be academically successful. In 
addition to academic success, readers develop themselves and contribute to the cultural, economic and social development of the society as well. Reading, which is perceived on an individual scale, is actually regarded as a social phenomenon involving individuality (Y1lmaz, 1995).

With the development of technology, the activities offered for spending free time have increased in terms of quantity and have varied in terms of quality. Seen as the cheapest tools for enjoying time, learning things and spending free time, traditional media such as books, newspapers and magazines are replaced by technological tools such as television, computer and internet. These tools can change some positive habits and behaviors existing in individuals, develop new attitudes and negatively affect individuals. These tools with an influence powerful enough to create a new lifestyle in children will inevitably affect reading, which is a social and individual habit. (Aral et al, 2011, Beentjes and Voort, 1988, Evra, 1998).

According to Temizyürek, et al. (2013), reading is a versatile skill which is not only the basic tool for acquiring knowledge, but which also totally affects the person on individual and social terms. Reading is not a process but a skill that has to be maintained for life. Reading is seen as a learning field that provides the greatest contribution to the development of the mind as during reading, the text is translated into mental concepts, is given meaning and structured in the brain (Güneş, 2007). Numerous studies have been carried out to emphasize the place and importance of reading in our lives and many opinions have been revealed in these studies. In most of these studies, reading has been presented as a way of success and development, leading to happiness as a result. However, it has also been pointed out in various studies that the ever-developing technology has come between the children and the books and that children prefer watching television and spending time on computer and internet to reading books (Aksaçlığlu and Yılmaz, 2007). Reading is important for everyone to handle new information in the changing world of technology. The importance and necessity of this will continue to increase every year. On the other hand, the number of people who know how to read but who don't read at a sufficient level also increases (Sangkaeo, 1999). According to the research by İpşiroğlu (1997), the majority of young people in our country do not read, do not comprehend what they read and cannot explain what they have understood or what they think.

Our age is the information age. Individuals growing up in this age are expected to search for and discover information and to convert such information into a product. Considering that teachers will cultivate individuals, they must have these qualities first (Y1lmaz and Benli, 2010). The act of reading with the aim of searching for and discovering new information is necessary for gaining professional formation, as well as gaining psycho-motor, affective and cognitive behaviors appropriate for teaching profession. At this point, physical education helps the socialization of the individual and plays a significant role in the development of his/her personality. It is also obvious that those who do sports are more assertive than those who don't and girls are more assertive than boys (Dervent et al., 2010). This is because physical education requires that individuals live in accordance with the society they are part of and that they be healthy on spiritual, mental and physical terms in order to properly manage relations with each other.

In the light of this information, the purpose of this research is to analyze the reading habits of students studying physical education and sports training with respect to certain variables.

\section{Method}

\subsection{Research Group}

A total of 324 first-year students studying in physical education and sports education departments of Kafkas University $(\mathrm{n}=146), 19$ May1s University $(\mathrm{n}=121)$ and Sinop University $(\mathrm{n}=56)$ in 2017-2018 Academic year, voluntarily participated in the research. 125 of these students $(38.6 \%)$ were female and 199 of them were male $(61.4 \%)$.

\subsection{Data Collection Tools}

In this research, the "attitude scale towards reading habit" and "personal information form" were applied to the participants using the general screening model among the descriptive research methods. Before the data collection tool was handed out, detailed information was given about filling in the data collection tool. Voluntary participation was sought for in the research and only those who were willing to fill in the questionnaire were handed out the data collection tool. Then, the data collected were checked and transferred to the computer environment for assessment.

\subsection{Attitude Scale Towards Reading Habit}

The "Attitude Scale Towards Reading Habit" was developed by Gömleksiz (2004) and was made valid and reliable. 
The scale consists of a total of 30 items (21 positive and 9 negative) and 6 sub-dimensions; Love (items 1, 3, 5, 6, 8, 16 and 20), Habit (items 2, 7, 18 and 27), Necessity 8items 4, 9, 11 and 13), Will (items 10, 12 and 29), Effect (items 14, 17, 25 and 30), Benefit (items 15, 19,21, 22, 23, 24, 26 and 28) and are scored in 5 point Likert scale ( $5=$ Strongly agree, $4=$ Agree, $3=$ Neither agree or disagree, $2=$ Disagree, $1=$ Strongly disagree). Inverse scoring was performed as items $1,2,3,4,5,6,7,9$ and 13 of the scale involved negative (inverse items) statements. Within the scope of the current study, the highest score that can be taken from the scale is 150.00 and the lowest score is 70.00 . In addition, a personal information form was employed, which was developed by the researcher to measure the socio-demographic characteristics of the students, consisting of the gender, age, department, mother's educational background, father's educational background and academic grade averages. According to the results of reliability analyses, internal consistency factor of the scale was 0.88 ; and as for the internal consistency factors of the sub-dimensions, love was 0.78 , habit 0.73 , necessity 0.72 , will 0,70 , effect 0.75 and benefit 0.79 . Reliability of the scale of attitudes towards reading habit was checked again in the research. As a result of the reliability analysis, internal consistency factor of the scale was 0.91 ; and as for the internal consistency factors of the sub-dimensions, love was 0.77 , habit 0.74 , necessity 0.78 , will 0.75 , effect 0.79 and benefit 0.91 .

\subsection{Data Analysis}

The data collected from the research were first subjected to Shapiro Wilk and Levene tests, which showed a normal distribution. Then, they were subjected to t-test and one-way ANOVA test. In multiple comparisons, the Tukey HSD test was used to determine the groups causing the difference. The significance level was accepted as $p<0.05$ in the analysis of the data.

\section{Results}

Table 1. Demographic Characteristics of Participants

\begin{tabular}{llcc}
\hline Variables & & $\mathrm{N}$ & $\%$ \\
\hline \multirow{2}{*}{ Gender } & Women & 125 & 38,6 \\
& Men & 199 & 61,4 \\
Age & $18-20$ & 188 & 58,0 \\
& $21-22$ & 96 & 29,6 \\
& $23-24$ & 31 & 9,6 \\
Department & 25 and over & 9 & 2,8 \\
& Physical Education and Sport Teaching & 67 & 20,7 \\
& Coaching Education & 151 & 46,6 \\
Mother's educational & Sports Management & 106 & 32,7 \\
background & Illiterate & 73 & 22,5 \\
& Primary school & 128 & 39,5 \\
& Secondary school & 65 & 20,1 \\
& High school & 40 & 12,3 \\
Father's educational & University & 18 & 5,6 \\
background & Illiterate & 24 & 7,4 \\
& Primary school & 108 & 33,3 \\
& Secondary school & 76 & 23,5 \\
& High school & 93 & 28,7 \\
Academic grade point & University & 23 & 7,1 \\
averages & $1,00-1,50$ & 15 & 4,6 \\
& $1,51-2,00$ & 65 & 20,1 \\
& $2,01-2,50$ & 95 & 29,3 \\
& $2,51-3,00$ & 94 & 29,0 \\
& 3,01 and over & 55 & 17,0 \\
\hline
\end{tabular}

Table 1 shows personal information about the students in the research. 
Table 2. Reading Habits of the Participants in Terms of the Gender Variable

\begin{tabular}{|c|c|c|c|c|c|c|}
\hline Sub-dimensions & Gender & $\mathbf{N}$ & $\mathbf{x}^{2}$ & Ss & $\mathbf{t}$ & P value \\
\hline \multirow{2}{*}{ Love } & Women & 125 & 16,10 & 5,274 & \multirow{2}{*}{2,733} & \multirow{2}{*}{$0,007 *$} \\
\hline & Men & 199 & 17,67 & 4,873 & & \\
\hline \multirow{2}{*}{ Habit } & Women & 125 & 8,32 & 3,166 & \multirow{2}{*}{3,427} & \multirow{2}{*}{$0,001 *$} \\
\hline & Men & 199 & 9,57 & 3,246 & & \\
\hline \multirow{2}{*}{ Necessity } & Women & 125 & 10,00 & 2,284 & \multirow{2}{*}{0,189} & \multirow{2}{*}{0,850} \\
\hline & Men & 199 & 10,06 & 2,515 & & \\
\hline \multirow{2}{*}{ Will } & Women & 125 & 6,17 & 2,443 & \multirow{2}{*}{2,885} & \multirow{2}{*}{$0,004 *$} \\
\hline & Men & 199 & 7,02 & 2,659 & & \\
\hline \multirow{2}{*}{ Effect } & Women & 125 & 7,74 & 2,975 & \multirow{2}{*}{3,012} & \multirow{2}{*}{$0,003 *$} \\
\hline & Men & 199 & 8,80 & 3,148 & & \\
\hline \multirow{2}{*}{ Benefit } & Women & 125 & 14,08 & 5,998 & \multirow{2}{*}{3,228} & \multirow{2}{*}{$0,001 *$} \\
\hline & Men & 199 & 16,54 & 7,067 & & \\
\hline
\end{tabular}

$\mathrm{P}<0,05$

Table 2 shows the result of the t-test; according to which there was a significant difference in favor of the female participants in the sub-dimensions of "love, habit, will, effect and benefit" $(p<0.05)$. There was no significant difference in terms of the sub-dimension of "necessity" $(p>0.005)$.

Table 3. Reading Habits of the Participants in Terms of the Age Variable

\begin{tabular}{|c|c|c|c|c|c|c|c|c|}
\hline Sub-dimensions & Age & $\mathbf{N}$ & $\mathbf{x}^{2}$ & Ss & Min. & Max. & P value & Difference \\
\hline \multirow{5}{*}{ Love } & $18-20$ & 188 & 17,52 & 4,96 & 7,00 & 31,00 & \multirow{4}{*}{0,250} & \multirow{4}{*}{ 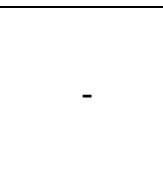 } \\
\hline & $21-22$ & 96 & 16,28 & 5,01 & 7,00 & 29,00 & & \\
\hline & $23-25$ & 31 & 17,03 & 5,71 & 7,00 & 27,00 & & \\
\hline & 25 and over & 9 & 16,11 & 5,60 & 9,00 & 24,00 & & \\
\hline & $18-20$ & 188 & 9,38 & 3,27 & 4,00 & 18,00 & \multirow{4}{*}{0,230} & \multirow{5}{*}{-} \\
\hline \multirow{3}{*}{ Habit } & $21-22$ & 96 & 8,79 & 3,41 & 4,00 & 18,00 & & \\
\hline & $23-25$ & 31 & 8,25 & 2,67 & 4,00 & 13,00 & & \\
\hline & 25 and over & 9 & 9,11 & 3,10 & 4,00 & 13,00 & & \\
\hline \multirow{5}{*}{ Necessity } & $18-20$ & 188 & 10,44 & 2,43 & 4,00 & 16,00 & \multirow{4}{*}{$0,003 *$} & \\
\hline & $21-22$ & 96 & 9,35 & 2,33 & 4,00 & 18,00 & & \multirow{3}{*}{$\begin{array}{l}18-20 \\
21-22\end{array}$} \\
\hline & $23-25$ & 31 & 9,80 & 2,35 & 5,00 & 15,00 & & \\
\hline & 25 and over & 9 & 9,66 & 1,93 & 8,00 & 13,00 & & \\
\hline & $18-20$ & 188 & 6,82 & 2,41 & 3,00 & 15,00 & \multirow{4}{*}{0,596} & \multirow{4}{*}{ - } \\
\hline \multirow{3}{*}{ Will } & $21-22$ & 96 & 6,48 & 2,81 & 3,00 & 14,00 & & \\
\hline & $23-25$ & 31 & 6,38 & 3,00 & 3,00 & 13,00 & & \\
\hline & 25 and over & 9 & 7,22 & 2,99 & 3,00 & 12,00 & & \\
\hline \multirow{4}{*}{ Effect } & $18-20$ & 188 & 8,30 & 3,09 & 4,00 & 17,00 & \multirow{4}{*}{0,667} & \multirow{4}{*}{ - } \\
\hline & $21-22$ & 96 & 8,62 & 3,27 & 4,00 & 17,00 & & \\
\hline & $23-25$ & 31 & 8,03 & 2,85 & 4,00 & 15,00 & & \\
\hline & 25 and over & 9 & 9,11 & 3,17 & 4,00 & 15,00 & & \\
\hline \multirow{4}{*}{ Benefit } & $18-20$ & 188 & 15,68 & 6,59 & 8,00 & 35,00 & \multirow{4}{*}{0,601} & \multirow{4}{*}{ - } \\
\hline & $21-22$ & 96 & 15,86 & 7,09 & 7,00 & 36,00 & & \\
\hline & $23-25$ & 31 & 14,06 & 6,50 & 8,00 & 31,00 & & \\
\hline & 25 and over & 9 & 16,33 & 8,32 & 8,00 & 30,00 & & \\
\hline
\end{tabular}

$\mathbf{p}<\mathbf{0 . 0 5}$

Table 3 shows the result of the ANOVA test, according to which there was a significant difference in the "necessity" sub-dimension of the reading habits $(\mathrm{p}<0.05)$. There was no difference in the sub-dimensions of "love, habit, will, effect and benefit" ( $\mathrm{p}>0.05)$. 
Table 4. Reading Habits of the Participants in Terms of the Department Variable

\begin{tabular}{|c|c|c|c|c|c|c|c|c|}
\hline Sub-dimensions & Department & $\mathbf{N}$ & $\mathbf{x}^{2}$ & Ss & Min. & Max. & P value & Difference \\
\hline \multirow{3}{*}{ Love } & Physical Edu. Teach. & 67 & 17,83 & 5,30 & 7,00 & 30,00 & \multirow{3}{*}{0,373} & \multirow{3}{*}{-} \\
\hline & Coaching Education & 151 & 16,92 & 4,96 & 7,00 & 31,00 & & \\
\hline & Sports Management & 106 & 16,78 & 5,09 & 7,00 & 29,00 & & \\
\hline \multirow{3}{*}{ Habit } & Physical Edu. Teach. & 67 & 9,62 & 3,67 & 4,00 & 16,00 & \multirow{3}{*}{0,291} & \multirow{3}{*}{-} \\
\hline & Coaching Education & 151 & 9,03 & 3,23 & 4,00 & 18,00 & & \\
\hline & Sports Management & 106 & 8,83 & 3,03 & 4,00 & 18,00 & & \\
\hline \multirow{3}{*}{ Necessity } & Physical Edu. Teach. & 67 & 10,17 & 2,58 & 5,00 & 18,00 & \multirow{3}{*}{0,821} & \multirow{3}{*}{-} \\
\hline & Coaching Education & 151 & 9,96 & 2,53 & 4,00 & 16,00 & & \\
\hline & Sports Management & 106 & 10,06 & 2,17 & 5,00 & 16,00 & & \\
\hline \multirow{3}{*}{ Will } & Physical Edu. Teach. & 67 & 7,14 & 2,68 & 3,00 & 13,00 & \multirow{3}{*}{0,180} & \multirow{3}{*}{-} \\
\hline & Coaching Education & 151 & 6,70 & 2,44 & 3,00 & 15,00 & & \\
\hline & Sports Management & 106 & 6,39 & 2,75 & 3,00 & 15,00 & & \\
\hline \multirow{3}{*}{ Effect } & Physical Edu. Teach. & 67 & 8,86 & 3,25 & 4,00 & 17,00 & \multirow{3}{*}{0,382} & \multirow{3}{*}{-} \\
\hline & Coaching Education & 151 & 8,29 & 3,02 & 4,00 & 16,00 & & \\
\hline & Sports Management & 106 & 8,24 & 3,17 & 4,00 & 17,00 & & \\
\hline \multirow{3}{*}{ Benefit } & Physical Edu. Teach. & 67 & 16,52 & 6,92 & 8,00 & 33,00 & \multirow{3}{*}{0,442} & \multirow{3}{*}{-} \\
\hline & Coaching Education & 151 & 15,45 & 6,70 & 7,00 & 36,00 & & \\
\hline & Sports Management & 106 & 15,22 & 6,77 & 8,00 & 35,00 & & \\
\hline
\end{tabular}

Table 4 shows that book reading habits of the participants show no significant difference with respect to the department variable $(\mathrm{p}>0.05)$.

Table 5. Reading Habits of the Participants in Terms of the Variable of Mother's Educational Background

\begin{tabular}{|c|c|c|c|c|c|c|c|c|}
\hline Sub-dimensions & Mother's Education & $\mathbf{N}$ & $\mathbf{x}^{2}$ & Ss & Min. & Max. & P value & Difference \\
\hline \multirow{5}{*}{ Love } & Illiterate & 73 & 17,02 & 5,03 & 7,00 & 30,00 & \multirow{5}{*}{0,974} & \multirow{5}{*}{-} \\
\hline & Primary school & 128 & 16,96 & 4,89 & 7,00 & 30,00 & & \\
\hline & Secondary school & 65 & 17,15 & 4,93 & 7,00 & 28,00 & & \\
\hline & High school & 40 & 17,00 & 5,84 & 7,00 & 31,00 & & \\
\hline & University & 18 & 17,83 & 5,75 & 7,00 & 27,00 & & \\
\hline \multirow{5}{*}{ Habit } & Illiterate & 73 & 8,63 & 3,14 & 4,00 & 16,00 & \multirow{5}{*}{0,363} & \multirow{5}{*}{-} \\
\hline & Primary school & 128 & 9,15 & 3,19 & 4,00 & 18,00 & & \\
\hline & Secondary school & 65 & 9,10 & 3,19 & 4,00 & 16,00 & & \\
\hline & High school & 40 & 9,12 & 3,36 & 4,00 & 17,00 & & \\
\hline & University & 18 & 10,38 & 4,24 & 4,00 & 18,00 & & \\
\hline \multirow{5}{*}{ Necessity } & Illiterate & 73 & 9,53 & 2,24 & 5,00 & 15,00 & \multirow{5}{*}{0,164} & \multirow{5}{*}{-} \\
\hline & Primary school & 128 & 9,99 & 2,62 & 4,00 & 18,00 & & \\
\hline & Secondary school & 65 & 10,24 & 2,05 & 6,00 & 15,00 & & \\
\hline & High school & 40 & 10,45 & 2,41 & 6,00 & 16,00 & & \\
\hline & University & 18 & 10,77 & 2,73 & 6,00 & 15,00 & & \\
\hline \multirow{5}{*}{ Will } & Illiterate & 73 & 6,46 & 2,73 & 3,00 & 14,00 & \multirow{5}{*}{0,874} & \multirow{5}{*}{-} \\
\hline & Primary school & 128 & 6,78 & 2,60 & 3,00 & 14,00 & & \\
\hline & Secondary school & 65 & 6,73 & 2,41 & 3,00 & 12,00 & & \\
\hline & High school & 40 & 6,60 & 2,84 & 3,00 & 15,00 & & \\
\hline & University & 18 & 7,11 & 2,39 & 3,00 & 15,00 & & \\
\hline \multirow{5}{*}{ Effect } & Illiterate & 73 & 8,01 & 2,88 & 4,00 & 17,00 & \multirow{5}{*}{0,384} & \multirow{5}{*}{-} \\
\hline & Primary school & 128 & 8,73 & 3,19 & 4,00 & 17,00 & & \\
\hline & Secondary school & 65 & 8,09 & 3,08 & 4,00 & 14,00 & & \\
\hline & High school & 40 & 8,20 & 3,11 & 4,00 & 16,00 & & \\
\hline & University & 18 & 9,05 & 3,63 & 4,00 & 16,00 & & \\
\hline \multirow{5}{*}{ Benefit } & Illiterate & 73 & 8,39 & 3,12 & 4,00 & 17,00 & \multirow{5}{*}{0,719} & \multirow{5}{*}{-} \\
\hline & Primary school & 128 & 15,00 & 6,45 & 8,00 & 33,00 & & \\
\hline & Secondary school & 65 & 16,25 & 7,17 & 8,00 & 34,00 & & \\
\hline & High school & 40 & 15,32 & 6,30 & 7,00 & 31,00 & & \\
\hline & University & 18 & 15,37 & 7,08 & 8,00 & 36,00 & & \\
\hline
\end{tabular}


Table 5 shows that reading habits of the participants show no significant difference with respect to the variable of mother's educational background ( $\mathrm{p}>0.05$ ).

Table 6. Reading Habits of the Participants in Terms of the Variable of Father's Educational Background

\begin{tabular}{|c|c|c|c|c|c|c|c|c|}
\hline Sub-dimensions & Father's Education & $\mathbf{N}$ & $\mathbf{x}^{2}$ & Ss & Min. & Max. & P-value & Difference \\
\hline \multirow{5}{*}{ Love } & Illiterate & 24 & 17,41 & 5,22 & 8,00 & 27,00 & \multirow{5}{*}{0,328} & \multirow{5}{*}{-} \\
\hline & Primary school & 108 & 16,30 & 4,75 & 7,00 & 30,00 & & \\
\hline & Secondary school & 76 & 17,89 & 5,19 & 7,00 & 28,00 & & \\
\hline & High school & 93 & 17,11 & 5,37 & 7,00 & 31,00 & & \\
\hline & University & 23 & 17,34 & 4,84 & 8,00 & 26,00 & & \\
\hline \multirow{5}{*}{ Habit } & Illiterate & 24 & 9,04 & 3,15 & 4,00 & 16,00 & & \multirow{5}{*}{$\begin{array}{c}\text { Primary and } \\
\text { Secondary } \\
\text { School }\end{array}$} \\
\hline & Primary school & 108 & 8,29 & 3,04 & 4,00 & 18,00 & & \\
\hline & Secondary school & 76 & 9,60 & 3,07 & 4,00 & 16,00 & $0,034 *$ & \\
\hline & High school & 93 & 9,44 & 3,40 & 4,00 & 17,00 & & \\
\hline & University & 23 & 9,78 & 3,93 & 4,00 & 18,00 & & \\
\hline \multirow{5}{*}{ Necessity } & Illiterate & 24 & 9,41 & 2,22 & 6,00 & 15,00 & & \multirow{5}{*}{$\begin{array}{c}\text { Primary and } \\
\text { Secondary } \\
\text { School }\end{array}$} \\
\hline & Primary school & 108 & 9,50 & 2,40 & 4,00 & 16,00 & & \\
\hline & Secondary school & 76 & 10,67 & 2,38 & 4,00 & 18,00 & $0,009 *$ & \\
\hline & High school & 93 & 10,17 & 2,41 & 5,00 & 16,00 & & \\
\hline & University & 23 & 10,56 & 2,37 & 7,00 & 15,00 & & \\
\hline \multirow{5}{*}{ Will } & Illiterate & 24 & 6,58 & 3,33 & 3,00 & 14,00 & & \multirow{5}{*}{$\begin{array}{c}\text { Primary and } \\
\text { Secondary } \\
\text { School }\end{array}$} \\
\hline & Primary school & 108 & 6,21 & 2,58 & 3,00 & 14,00 & & \\
\hline & Secondary school & 76 & 7,43 & 2,42 & 3,00 & 13,00 & $\mathbf{0 , 0 3 4 *}$ & \\
\hline & High school & 93 & 6,77 & 2,62 & 3,00 & 15,00 & & \\
\hline & University & 23 & 6,34 & 1,92 & 3,00 & 9,00 & & \\
\hline \multirow{5}{*}{ Effect } & Illiterate & 24 & 8,50 & 3,37 & 4,00 & 17,00 & \multirow{5}{*}{0,323} & \multirow{5}{*}{-} \\
\hline & Primary school & 108 & 8,04 & 3,03 & 4,00 & 17,00 & & \\
\hline & Secondary school & 76 & 8,80 & 3,03 & 4,00 & 16,00 & & \\
\hline & High school & 93 & 8,63 & 3,26 & 4,00 & 17,00 & & \\
\hline & University & 23 & 7,60 & 2,87 & 4,00 & 15,00 & & \\
\hline \multirow{5}{*}{ Benefit } & Illiterate & 24 & 15,08 & 7,46 & 8,00 & 33,00 & \multirow{5}{*}{0,261} & \multirow{5}{*}{-} \\
\hline & Primary school & 108 & 14,88 & 6,67 & 7,00 & 34,00 & & \\
\hline & Secondary school & 76 & 16,85 & 7,06 & 8,00 & 36,00 & & \\
\hline & High school & 93 & 15,9 & 6,57 & 8,00 & 35,00 & & \\
\hline & University & 23 & 14,08 & 6,02 & 8,00 & 31,00 & & \\
\hline
\end{tabular}

$\mathrm{p}<0,05$

Table 6 shows a significant difference between primary school and secondary school in terms of the sub-dimensions of "habit, necessity and will" concerning the variable of father's educational background $(p<0.05)$. On the other hand, there is no significant difference in sub-dimensions of "love, effect, benefit" ( $p>0.05)$. 
Table 7. Reading Habits of the Participants in Terms of Their Academic Grade Point Averages

\begin{tabular}{|c|c|c|c|c|c|c|c|c|}
\hline Sub-dimensions & Academic & $\mathbf{N}$ & $x^{2}$ & Ss & Min. & Max. & P value & Difference \\
\hline \multirow{5}{*}{ Love } & $1,00-1,50$ & 15 & 14,40 & 4,77 & 7,00 & 26,00 & \multirow{5}{*}{$0,005 *$} & \multirow{2}{*}{$\begin{array}{c}1,51-2,00 \\
2,51-3,00\end{array}$} \\
\hline & $1,51-2,00$ & 65 & 17,78 & 4,98 & 7,00 & 30,00 & & \\
\hline & $2,01-2,50$ & 95 & 17,84 & 5,22 & 7,00 & 31,00 & & \\
\hline & $2,51-3,00$ & 94 & 17,26 & 4,88 & 8,00 & 30,00 & & $2,01-2,50 \_3,00$ \\
\hline & 3,00 and over & 55 & 15,27 & 4,84 & 7,00 & 26,00 & & \\
\hline \multirow{5}{*}{ Habit } & $1,00-1,50$ & 15 & 7,20 & 3,32 & 4,00 & 16,00 & \multirow{5}{*}{0,058} & \\
\hline & $1,51-2,00$ & 65 & 9,10 & 2,82 & 4,00 & 15,00 & & \\
\hline & $2,01-2,50$ & 95 & 9,65 & 3,37 & 4,00 & 18,00 & & - \\
\hline & $2,51-3,00$ & 94 & 9,10 & 3,42 & 4,00 & 18,00 & & \\
\hline & 3,00 and over & 55 & 8,60 & 3,11 & 4,00 & 16,00 & & \\
\hline \multirow{5}{*}{ Neccessity } & $1,00-1,50$ & 15 & 9,46 & 2,23 & 7,00 & 16,00 & \multirow{5}{*}{0,139} & \multirow{5}{*}{-} \\
\hline & $1,51-2,00$ & 65 & 10,23 & 2,23 & 5,00 & 15,00 & & \\
\hline & $2,01-2,50$ & 95 & 10,37 & 2,47 & 4,00 & 18,00 & & \\
\hline & $2,51-3,00$ & 94 & 10,03 & 2,57 & 4,00 & 16,00 & & \\
\hline & 3,00 and over & 55 & 9,40 & 2,26 & 5,00 & 15,00 & & \\
\hline \multirow{5}{*}{ Will } & $1,00-1,50$ & 15 & 5,33 & 2,69 & 3,00 & 11,00 & \multirow{5}{*}{0,067} & \multirow{5}{*}{-} \\
\hline & $1,51-2,00$ & 65 & 7,00 & 2,59 & 3,00 & 13,00 & & \\
\hline & $2,01-2,50$ & 95 & 7,10 & 2,84 & 3,00 & 15,00 & & \\
\hline & $2,51-3,00$ & 94 & 6,42 & 2,34 & 3,00 & 14,00 & & \\
\hline & 3,00 and over & 55 & 6,47 & 2,48 & 3,00 & 11,00 & & \\
\hline \multirow{5}{*}{ Effect } & $1,00-1,50$ & 15 & 7,20 & 2,36 & 4,00 & 13,00 & \multirow{5}{*}{0,161} & \multirow{5}{*}{-} \\
\hline & $1,51-2,00$ & 65 & 9,01 & 3,23 & 4,00 & 17,00 & & \\
\hline & $2,01-2,50$ & 95 & 8,61 & 3,13 & 4,00 & 16,00 & & \\
\hline & $2,51-3,00$ & 94 & 8,15 & 3,14 & 4,00 & 17,00 & & \\
\hline & 3,00 and over & 55 & 8,01 & 3,02 & 4,00 & 16,00 & & \\
\hline \multirow{5}{*}{ Benefit } & $1,00-1,50$ & 15 & 11,66 & 4,20 & 8,00 & 21,00 & \multirow{5}{*}{$\mathbf{0 , 0 2 2 *}$} & \multirow{5}{*}{$\begin{array}{c}1,00-1,50 \_1,51-2,00 \\
2,01-2,50\end{array}$} \\
\hline & $1,51-2,00$ & 65 & 16,70 & 7,09 & 8,00 & 36,00 & & \\
\hline & $2,01-2,50$ & 95 & 16,57 & 7,02 & 8,00 & 35,00 & & \\
\hline & $2,51-3,00$ & 94 & 15,29 & 6,67 & 8,00 & 34,00 & & \\
\hline & 3,00 and over & 55 & 14,18 & 6,14 & 7,00 & 31,00 & & \\
\hline
\end{tabular}

$\mathrm{p}<0,05$

Table 7 shows a significant difference in sub-dimensions of "love and benefit" as a result of the ANOVA test carried out according to the academic grade point averages of the participants $(p<0.05)$. On the other hand, there is no significant difference in sub-dimensions of "habit, necessity, will and effect" $(p>0.05)$.

\section{Discussion}

In this research, the reading habits of university students studying Physical Education and Sports Training were analyzed in terms of certain variables. According to the results of the research, a significant difference was found in favor of women in the age variable of sub-dimensions of "love, habit, will, effect and benefit"; in the gender variable; in favor of ages 18-20-21-22 in sub-dimension of "necessity" ; in favor of primary and secondary school graduates in sub-dimensions of "habit, necessity and will" in the father's educational background variable; in favor of the average value above 1.5 in sub-dimension of "love" and in favor of average grades between 1.0-2.5 in sub-dimension of "benefit" in the academic grade averages variable $(\mathrm{p}<0.05)$. No significant difference was found with respect to the variables of the department and mother's education background $(\mathrm{p}>0.05)$.

When we examine the pieces of research on book reading, we can say that our work is similar to the ones in the 
literature. The studies on university students consistently show a general tendency among the students, which is that they do not read books sufficiently and they do not prefer to read books in their free time. In our research, it was observed that university students studying Physical Education and Sports Training rarely read books and that female students read books more than male students.

In their research, Yilmaz et al. (2009) found that the students of the two universities participating in the survey had a poor reading habit. In another piece of research carried out by Sracoğlu et al. (2003), teacher candidates were found to have an insufficient level of reading habit. It was also revealed out at the end of the research that female students were more interested in reading than male students. Similarly, in a research carried out by Akçakaya et al. (2012) it was stated that there was a significant difference in favor of girls in sub-dimensions of love, habit, will, influence and benefit dimensions of students' reading habits. In other pieces of research carried out in Turkey, it was found that female students read books more than male students and spare more time to read books. (Arslantürk and Saracaloğlu 2010; Can et al. 2010; Mavi and Çetin 2009). Gömleksiz (2004) and Göksel et al. (2016) also found significant differences in favor of female students in the sub-dimensions of the book reading habit in different subject groups.

In a piece of research where Balc1 (2003) studied the free time activities of university students in Ankara; among a total of 803 ( 385 females, 418 males) students, only two of them were determined to read books in their free time. The fact that students who mostly spend their free time on computer and internet are steered away from book reading that much is emphasized as an issue of concern. As a result of the research carried out by Odabaş et al. (2008) regarding the book reading habits of university students, it was found that reading skills of the students improve during their higher education, and yet, they do not have a sufficient level of reading habit. In their research, Akçakaya et al. (2012) found no significant difference in the relationship between the mother's educational background and book reading habit. In another study, statistically significant differences were found in the attitudes of social studies teacher candidates towards reading habit in terms of the variables of gender, mother's educational background, reading frequency and total number of books read whereas no difference was found in terms of the variables of class and father's educational background. They concluded that there should be activities that will have a positive effect on attitudes towards reading habit at all levels of education (Durmuş et al. 2016).

Yllmaz (2010) found that almost half of the nursing students (49.1\%) had a moderate level of book reading habit and $13 \%$ of them had a good level of book reading habit. In a piece of research carried out in 2016, it was found that female students read books more than male students and no difference was found between the students interested in individual and team sports (Göksel et al. 2016). Tel et al. (2007) found that Physical Education and Sports students don't have book reading habits and they mostly spend their free time on sports activities. The rate of library visit has been found to be rather low among the students. As the reasons for not reading books, students participating in the research stated that they spend too much time on television and the school doesn't encourage reading books. In another study carried out on the students of Higher School of Physical Education and Sports (Filiz, 2004), it was concluded that the tendency to read books is increasingly declining among university students, students do not go to library for research, unless inevitable and they do not give sufficient efforts to obtain professional information.

It was revealed out in the research that among the university students studying Physical Education and Sports, female students have a greater level of book reading habit. Those whose father is primary or secondary school graduate are more willing to read books and they regard this habit as a necessity. Similar to the studies in the literature, it also draws attention that university students of today do not have a sufficient level of book reading habit. It is worrying for our society that book reading habit at universities is rather low while we expect it to be highest at universities. Therefore, involving further activities that will develop this habit, making necessary arrangements in the circles of friends, family and in the environmental conditions, conducting works to encourage book reading at all levels of education, particularly including the university will all help us raise better qualified individuals for our country.

\section{References}

Akçakaya, M., Demir, T., Gündoğan, S., Işık, A., Şenol, R., Türksoy, İ., Yeşilyaprak, N., Keçeci, A., Çelik, S., \& Akkaş, A.Ö.(2012). Attidutes of Nursing Students towards Reading Habits: A Vocational School Sample. Florence Nightingale Journal of Nursing, 20(2), 120-128.

Aksaçlığlu, A.G., \& Yılmaz, B. (2007). Impacts of Watching Television and Computer Using on Students' Reading Habits. The Journal of Turkish Librarianship, 21(1), 3-28.

Aral, N., Ceylan, R., \& Bıçakçı M.Y. (2011). Study of Television Viewing Habits of Children by Age and Gender. Kastamonu Educational Journal, 19(2), 489-498. 
Arslantürk, E., \& Saracaloğlu, A. S. (2010). Comparison of Elementary School Teachers and Prospective Elementary Teachers' Reading Interests and Reading Habits. Anadolu University Journal of Social Sciences, 11(1), $155-176$

Balc1, V. (2003). Researching the Participation of Ankara University Students in Leisure Activities. National Education Journal, 158, 161-173.

Beentjes, J.W.H., \& Voort, T.H.A. (1988). Television's Impact on Children's Reading Skills: A Review of Research. Reading Research Quarterly, 23, 389-413. https://doi.org/10.2307/747640

Can, R., Türkyılmaz, M., \& Karadeniz, A. (2010). Adolescent Students' Reading Habits. Ahi Evran University Journal of Kırşehir Education Faculty, 11(3), 1-21.

Dervent, F., Arslanoğlu, E., \& Şenel, Ö. (2010). Agressivity levels of the high school students and relation with their participation to sport activities (Sample of Istanbul) Journal of Human Sciences, 7(1), 521-533.

Durmuş, E., \& Baş, K. (2016). Analysis of Book Reading Habits Attitudes of Social Studies Pre-Service Teachers.Abant İzet Baysal University Journal of Faculty of Education, 16(Special Issue II), 1240-1254.

Evra, J.V. (1998). Television and Child Development. New Jersey: Lawrance Erlbaum Associates.

Filiz, K. (2004). Habits of Reading and Research on their Profession of the Students in Gazi University School of Physical Education and Sports. Gazi University Journal of Gazi Educational Faculty, 24(2), 231-242.

Geçgel, H., \& Burgul, F. (2009). Interested Reading Area of Education Faculty Studets (Çanakkale Case). Tübav Journal of Science, 2(3), 341-353.

Göksel, A.G., Caz, Ç., Zorba, E., \& Gümüşdağ, H. (2016). Reading Habit: A Study on University Students Interested in Individual and Team Sports. Academic Sight International Refereed Online Journal of Social Sciences, 55, 195-206.

Gömleksiz, M.N. (2004). Validity and Reliability of an Attitude Scale Towards Reading Habit. Firat University Journal of Social Sciences, 14(2), 185-195.

Güneş, F. (2007). Türkçe Öğretimi Zihinsel Yapılandırma. Ankara: Nobel Publication.

İpşiroğlu, Z. (1997). E Eğitimde Yeni Araylşlar. Adam Publication, İstanbul.

Mavi, H.F., \& Çetin, B. (2009). Examination of Book Reading Views and Attitudes of Physical Education Teacher Candidates. Original Research, BESBD, 4(1), 1-11.

Odabaş, H., Odabaş, Z. Y., \& Polat, C. (2008). Reading Habit of Students: The Model of Ankara University. Information World, 9(2), 431-465.

Sangkaeo, S. (1999). Reading Habit Promotion in Asean Libraries. 65. Ifla Council and General Conference. 20-28 Ağustos 1999, Bangkok, Tayland. Retrieved from https://files.eric.ed.gov/fulltext/ED441496.pdf

Saracoğlu A.S., Bozkurt, N., \& Serin, O. (2003). Factors Affecting Reading Attitudes and Reading Habits of University Students. Eurasian Journal of Educational Research, 4(12), 149-157.

Şahin, A. (2012). A Study of 4th and 5th Grade Elemantary Students' Reading Habits, Based on Their Socio-Economic Status. The Journal of Turkish Educational Sciences, 10(2), 367-388.

Tel, M., Öcalan, M., Ramazanoğlu, F., \& Demirel, E.T. (2007). Reading Habits of Physical Education and Sport Students Depending on Some Socio-Economic Variables. Firat University Journal of Social Science, 17(1), 185-199.

Temizyürek, F., Çolakoğlu, B., \& Coşkun, S. (2013). Investigation of Reading Habits of the Ninth Grade Students According to Some Variables. The Journal of Turkish Educational Sciences, 11(2), 114-150.

Yllmaz, B., (1995). Sociology of Reading: An Investigation of Reading Habits of People Living in Ankara. The Journal of Turkish Librarianship, 9(3), 325-336.

Yılmaz, B., Köse, E., \& Korkut, Ş. (2009). A Research on Reading Habits of Hacettepe University and Bilkent University Students. The Journal of Turkish Librarianship, 23(1), 22-51.

Y1lmaz, D. E. (2010). Nursing students' critical thinking levels and attitudes towards reading habit. Master Thesis, Hacettepe University, Health Science Institute, Ankara.

Yılmaz, M., \& Benli, N. (2010). Analyzing Pre-Service Classroom Teacher Candidates' Attitudes Towards Reading Habit According to Some Variables. Erzincan University Journal of Education Faculty, 12(1), 281-291. 